\title{
Wpływ szybkości internacjonalizacji i kapitału zagranicznego na intensywność eksportu: przypadek startupów międzynarodowych
}

\author{
Krystian Bigos
}

\begin{abstract}
A B S T R A K T
Cel artykułu: Głównym celem artykułu jest zaprezentowanie wyników badań nad startupami międzynarodowymi, z uwzględnieniem znaczenia szybkości internacjonalizacji oraz kapitału zagranicznego w wyjaśnianiu intensywności ich eksportu na przykładzie krajów Grupy Wyszehradzkiej.

Metodyka badań: Artykuł, oprócz krytycznego przeglądu literatury, opiera się na danych zebranych w ramach badania BEEPS, które zostało przeprowadzone wśród przedsiębiorstw zlokalizowanych w krajach post-komunistycznych w Europie i Azji Środkowej. Po przeprowadzeniu odpowiedniej selekcji wybrano ostatecznie 158 startupów międzynarodowych pochodzących z Polski, Czech, Słowacji i Węgier. W badaniu sprawdzono istnienie zależności pomiędzy intensywnością eksportu startupu międzynarodowego a szybkością jego internacjonalizacji. Ponadto, zbadano również wpływ kapitału zagranicznego na intensywność eksportu startupu międzynarodowego.

Wyniki: Umiędzynarodowienie startupów przebiega szybko. Wyniki badania pokazują, że udział kapitału zagranicznego w strukturze właścicielskiej startupu ma duże znaczenie, gdyż przyczynia się do zwiększenia intensywności jego eksportu.

Wkład i wartość dodana: Artykuł ma na celu wzbogacenie trwającego dyskursu naukowego na temat roli kapitału zagranicznego i szybkości internacjonalizacji w startupach międzynarodowych.

Typ artykułu: oryginalny artykuł badawczy startup międzynarodowy; międzynarodowe nowe przedsięwzię-

Słowa kluczowe: cia; kapitał zagraniczny; szybkość internacjonalizacji; intensywność eksportu

Kody JEL: $\quad$ F23, L26, M13

Artykuł nadesłano: 12 Stycznia 2019 Artykuł zaakceptowano: 29 marca 2019
\end{abstract}

\section{Sugerowane cytowanie:}

Bigos, K. (2019). Wpływ szybkości internacjonalizacji i kapitału zagranicznego na intensywność eksportu: przypadek startupów międzynarodowych. International Entrepreneurship Review (previously published as International Entrepreneurship / Przedsiębiorczość Międzynarodowa), 5(1), 9-21. https://doi.org/10.15678/IER.2019.0501.01 


\section{WPROWADZENIE}

Jedna z pierwszych prób wyjaśnienia internacjonalizacji małych i średnich przedsiębiorstw (MŚP) została podjęta w połowie lat 70. XX w. i była związana z badaniem szwedzkich naukowców Johansona i Vahlne (1974). Badacze zaprezentowali uppsalski model internacjonalizacji, który należy do grupy modeli etapowych (Johanson \& Vahlne, 1977; Johanson \& Wiedersheim-Paul, 1975; Wach, 2012). Niemniej jednak w literaturze przedmiotu możemy spotkać również inne modele internacjonalizacji, jak choćby modele podejścia strategicznego (Bell, Crick \& Young, 2004; Hagen, Zucchella, Cerchiello \& de Giovanni, 2012) czy modele oparte na wiedzy (Mejri \& Umemoto, 2010).

Niebagatelny wkład w rozwój teorii internacjonalizacji małych i średnich przedsiębiorstw wniosła istniejąca od przeszło dwudziestu paru lat szkoła przedsiębiorczości międzynarodowej, której początki związane są z artykułami m.in. McDougall (1989) i Zahry (1993). Wach $(2015,2018)$ zwraca uwagę na fakt, że przedsiębiorczość międzynarodową należy traktować dychotomicznie, tj. zarówno jako obszar badawczy w zakresie teorii przedsiębiorczości postrzeganej jako autonomiczny obszar badań, jak i jako jedno z podejść badawczych nawiązujących do zagadnień internacjonalizacji w przedsiębiorstwach. Zdaniem Zahry (2005) w ramach podejścia szkoły przedsiębiorczości międzynarodowej należy wyodrębnić cztery nurty, które wyjaśniają internacjonalizację przedsiębiorstw: ogólne modele przedsiębiorczości międzynarodowej (Etemad, 2004; Ruzzier, Hisrich \& Antoncic, 2006; Schweizer, Vahlne \& Johanson, 2010), model urodzonych globalistów (Knight, Madsen \& Servais, 2004; McNaughton \& Bell, 2004), modele przyśpieszonej internacjonalizacji (Hashai \& Almor, 2004; Kalinic \& Forza, 2012) oraz modele międzynarodowych nowych przedsięwzięć (Oviatt \& McDougall, 1994).

Startupy międzynarodowe, znane również pod nazwą międzynarodowych nowych przedsięwzięć, odrywają szczególną rolę w gospodarce światowej. Wcześniejsze badania nad startupami międzynarodowymi skupiały się na wyjaśnianiu znaczenia wiedzy i zasobów w ich funkcjonowaniu (Maciejewski, 2018). W swoich badaniach naukowcy kładli również nacisk na objaśnianie kwestii wielkości przedsiębiorstwa oraz czasu, w którym powinno ono wchodzić na rynki zagraniczne (Duliniec, 2011), gdyż te aspekty nie zostały szczegółowo skomentowane w opracowaniu Oviatt i McDougall (1994). Obecnie część badaczy skupia swoją uwagę na tzw. zjawisku „korzyści płynących z uczenia się, jakie daje nowość" (ang. learning advantage of newness), które to oparte jest na założeniu, że startupy międzynarodowe w porównaniu do klasycznych form przedsiębiorstw mają prawdopodobnie większe możliwości w zakresie przyswajania nowych informacji o rynkach zagranicznych, rozpoznawania szans i szybkiego działania na nich (Autio, Sapienza \& Almeida, 2000; Ciszewska-Mlinarič, 2018; Zahra, Zheng \& Yu, 2018).

Szybkość internacjonalizacji jest ważnym zagadnieniem zarówno dla menedżerów wchodzących na międzynarodowe rynki, jak i dla badaczy biznesu międzynarodowego. Z menedżerskiego punktu widzenia, przedsiębiorstwa muszą zdecydować, w jakim tempie rozwijać się na arenie międzynarodowej, stąd szybkość ta jest istotnym zagadnieniem w kontekście wyznaczania międzynarodowej strategii i powinna równoważyć zasoby przedsiębiorstw i możliwości międzynarodowe. Szybkość internacjonalizacji jest również istotna z punktu widzenia nauki, ponieważ badacze nie udzielili wystarczających odpowiedzi m.in. na temat tego jak zarządzać i mierzyć szybkość internacjonalizacji (Chetty, 
Johanson, \& Martín Martín, 2014). Niestety wciąż brak jest wystarczającej liczby badań nad znaczeniem szybkości internacjonalizacji i kapitału zagranicznego w wyjaśnianiu intensywności eksportu startupów międzynarodowych, stąd zapełnienie wymienionej luki badawczej stanowi równocześnie cel niniejszego opracowania.

Artykuł ma następującą strukturę: w pierwszej części dokonano przeglądu literatury przedmiotu skupiając się w głównej mierze na charakterystyce startupów międzynarodowych oraz wpływie szybkości internacjonalizacji i udziału kapitału zagranicznego w strukturze właścicielskiej tych przedsięwzięć na intensywność ich eksportu. W drugiej części opracowania przeprowadzono analizę empiryczną z wykorzystaniem regresji liniowej.

\section{PRZEGLĄD LITERATURY}

Od mniej więcej początku lat 90. ubiegłego wieku w badaniach nad internacjonalizacją przedsiębiorstw zaczęto uwzględniać małe i średnie przedsiębiorstwa (MŚP). Badania te początkowo były oparte na wcześniej znanych teoriach internacjonalizacji (Wach, 2012). Niebagatelny wkład w rozwój teorii internacjonalizacji wniosła szkoła przedsiębiorczości międzynarodowej, której założycielami są m.in. McDougall oraz Oviatt. Opublikowany przez nich artykuł pt. „Toward a Theory of International New Ventures” (Oviatt \& McDougall, 1994) stał się przełomowym (za co z resztą kilka lat później badacze otrzymali nagrodę „Decade Award Winning Article”). W artykule tym zdefiniowali oni międzynarodowe nowe przedsięwzięcia (z ang. international new ventures - INV) jako organizacje biznesowe, które od samego początku swojej działalności dążą do uzyskania znaczącej przewagi konkurencyjnej dzięki wykorzystaniu odpowiednich zasobów oraz realizowaniu sprzedaży produkcji w wielu krajach (Oviatt \& McDougall, 1994). Cechą wyróżniającą te organizacje jest ich międzynarodowe pochodzenie, o czym świadczy m.in. znaczące zaangażowanie zasobów w więcej niż jednym kraju. Twórcy zaznaczają, że w modelu INV kładzie się szczególny nacisk na wiek, a nie wielkość przedsiębiorstwa oraz na to, że przedsięwzięcia te zaczynają swoją ekspansję zagraniczną od proaktywnej strategii marketingowej. Kontynuatorem koncepcji badaczy Oviatt i McDougall był Zahra (1993), który rozszerzył definicję INV o funkcjonujące już na rynku przedsiębiorstwa międzynarodowe.

Startupy międzynarodowe muszą sprostać trzem rodzajom zobowiązań identyfikowanych jako nowość (1), małość (2) oraz obcość (3), które zarówno pojedynczo, jak i w połączeniu z innymi czynnikami mogą zwiększyć ryzyko potencjalnego niepowodzenia tych przedsięwzięć (Turcan, 2013; Zahra, 2005). Na samym początku swojej działalności startupy międzynarodowe są nieznane opinii publicznej, co z kolei ma wpływ na ich zdolność do pozyskania zasobów oraz zajmowania pozycji w lokalnych i zagranicznych sieciach. Niewielkie rozmiary przedsiębiorstwa znacznie ograniczają możliwości pozyskania przez nie zasobów, które są im potrzebne do przetrwania i szybkiej internacjonalizacji (Zahra, 2005). W swoich rozważaniach Oviatt i McDougall zaznaczają, że startupy międzynarodowe nie zawsze prowadzą sprzedaży od samego początku, lecz skupiają się na działalności badawczo-rozwojowej mającej na celu opracowanie odpowiedniego międzynarodowego modelu biznesowego przedsięwzięcia ( $w$ tym opracowania odpowiedniego produktu lub/i usługi). Po zakończeniu wstępnej fazy z powodzeniem angażują swoje zasoby w sprzedaż produktu na wielu rynkach jednocześnie (Oviatt \& McDougall, 2005).

Badania nad startupami międzynarodowymi wydają się być uzasadnione głównie z powodu pogłębiającej się globalizacji. Bariery w dostępie do poszczególnych rynków 
są zdecydowanie niższe niż jeszcze kilkanaście lat temu. Główną przyczyną tego stanu rzeczy jest dynamiczny rozwój technologii (m.in. eCommerce), który z kolei zmniejsza koszt działalności międzynarodowej przedsiębiorstw (Knight \& Cavusgil, 2005). Internacjonalizacja startupów następuje szybko i w sposób proaktywny, krótko po rozpoczęciu działalności, co stoi w opozycji do klasycznych teorii procesowych podkreślających znaczenie powolnego procesu umiędzynarodowienia opartego na stabilnych rynku krajowym. Ich rozwój odbywa się skokowo, zaś wiedza stanowi bardzo istotny czynnik w przedwstępnej fazie internacjonalizacji (Schwens, Steinmetz \& Kabst, 2010).

W procesie internacjonalizacji przedsiębiorstwa, jedną z kluczowych decyzji strategicznych jest wybór odpowiedniego rynku docelowego (zagranicznego) (Ellis, 2000; Ellis \& Pecotich, 2001; Kumar, Stam \& Joachimsthaler, 1994; Papadopoulos, Chen \& Thomas, 2002). Wiąże się to z dużym zaangażowaniem zasobów zarówno strategicznych, jak i technicznych, zarządczych oraz finansowych (Monferrer, Blesa \& Ripollés, 2012), stąd nierzadko przedsiębiorstwo, ze względu na funkcjonowanie w warunkach występowania ograniczonych zasobów, musi podejmować ryzykowne decyzje w kontekście wyboru rynków docelowych (He \& Wei, 2011). Jest to szczególnie ważne w wypadku przedsiębiorstw, które chcą stać się międzynarodowymi od samego początku swojej działalności. Niemniej jednak niewiele wysiłku jak do tej pory włożono w wyjaśnienie kwestii dlaczego i w jaki sposób startupy międzynarodowe decydują się wchodzić na jeden lub więcej rynków zagranicznych (Monferrer i in., 2012). Przedsiębiorstwa te zauważają postępujące zmiany szybciej od pozostałych podmiotów gospodarczych przez co niezwłocznie dostosowują swoje działania do specyficznych potrzeb każdego rynku. Stąd też czynnik ten może odgrywać decydującą rolę w wyjaśnianiu nie tylko sposobu, w jaki startupy międzynarodowe pozyskują biznesowe i instytucjonalne informacje na temat rynków zagranicznych, lecz również w jaki sposób przetwarzają one pozyskaną informację rozwijając nową wiedzę (Armario, Ruiz \&Armario, 2008; Blesa, Ripolles \& Monferrer, 2010; Knight \& Cavusgil, 2004).

Nierzadko startupy międzynarodowe borykają się z problemem braku wystarczających zasobów finansowych, stąd muszą uciekać się do zewnętrznych źródeł finansowania, takich jak venture capital, które z roku na rok stają się coraz to bardziej popularne, szczególnie na rynkach krajów Grupy Wyszehradzkiej (OECD, 2017). Zdaniem naukowców z Uniwersytetu w Stanfordzie startupy finansowane za pomocą venture capital rosną znacznie szybciej niż te, które są finansowane z innych źródeł (Davila, Foster \& Gupta, 2003). Nierzadko inwestor oferujący finansowanie typu venture capital pełni rolę współzarządczą w startupie wnosząc do przedsiębiorstwa wiedzę i doświadczenie (Hellmann \& Puri, 2002). W krajach Grupy Wyszehradzkiej startupy międzynarodowe w głównej mierze są finansowane za pośrednictwem kapitału zagranicznego (Invest Europe, 2017), który z kolei może być źródłem wzrostu intensywności ich eksportu. Spowodowane to może być tym, że zagraniczni inwestorzy strategiczni mają motywację do zapewnienia przedsiębiorstwom portfelowym dostępu do ich sieci i zasobów kontraktualnych (Filatotchev, Hoskisson, Buck \& Wright, 1996; Pohl, Anderson, Claesson \& Dejankov, 1997).

\section{METODYKA BADAWCZA}

Wnioskowanie oparto przede wszystkim na danych zebranych w ramach badania BEEPS (z ang. Business Environment and Enterprise Performance Survey), które zostało przeprowadzone głównie wśród przedsiębiorstw mających swoją siedzibę w krajach post- 
komunistycznych w Europie i Azji Środkowej. Głównym celem wspomnianego badania było pozyskanie informacji od wybranych przedsiębiorstw na temat stanu sektora prywatnego. Pytania ankietowe odnosiły się m.in. do kwestii identyfikacji przedsiębiorstwa w sektorze (struktury właścicielskiej), określenia statusu prawnego i ekonomicznego przedsiębiorstw, charakterystyki kadry zarządzającej (np. wykształcenia i doświadczenia zawodowego).

Badanie BEEPS zostało przeprowadzone wśród przedsiębiorstw działających na rynku od co najmniej 3 lat oraz zatrudniających co najmniej 5 pracowników. Proces ankietowania odbywał się przy wsparciu wielu organizacji biznesowych oraz agencji rządowych odpowiedzialnych za promocję tworzenia miejsc pracy i wzrostu gospodarczego. W badaniu BEEPS odpowiedzi na pytania były udzielane przez właścicieli przedsiębiorstw bądź managerów wyższego szczebla w rozmowach bezpośrednich (ang. face-to-face interview).

Próbą objęto przedsiębiorstwa z sektora MŚP funkcjonujące w państwach należących do Grupy Wyszehradzkiej (Polska, Czechy, Słowacja, Węgry). Początkowo do analizy wybrano 537 przedsiębiorstw. Następnie wyeliminowano te podmioty, których dane były niekompletne. Za pomocą arkusza kalkulacyjnego obliczono różnicę pomiędzy rokiem założenia działalności gospodarczej a rokiem pierwszej zrealizowanej sprzedaży zagranicznej. W kolejnym kroku wyeliminowano te przedsiębiorstwa, których różnica wynosiła więcej niż 3 lata oraz których sprzedaż zagraniczna stanowiła mniej niż $25 \%$ sprzedaży ogółem. Jest to zgodne z kryterium zaproponowanym przez Jantunen i in. (2008), Knight i in. (2004) oraz Madsen, Rasmussen i Servais (2000).

Tabela 1. Statystyki opisowe

\begin{tabular}{|l|c|c|c|c|c|c|}
\hline Zmienna & Opis & $\mathbf{N}$ & Śr. & Odch. st. & Min & Max \\
\hline EXPORT & $\begin{array}{c}\text { Intensywność eksportu mierzona udziałem eks- } \\
\text { portu w sprzedaży ogółem }\end{array}$ & 158 & 0,643 & 0,255 & 25 & 100 \\
\hline AGE & $\begin{array}{c}\text { Wiek startupu w momencie pierwszej interna- } \\
\text { cjonalizacji }\end{array}$ & 158 & 0,930 & 1,273 & 0 & 3 \\
\hline FCAPITAL & $\begin{array}{c}\text { Udział kapitału zagranicznego w strukturze wła- } \\
\text { ścicielskiej startupu }\end{array}$ & 158 & 0,168 & 0,359 & 0 & 100 \\
\hline
\end{tabular}

Źródło: opracowanie własne.

Spośród pierwotnej liczebności próby ostatecznie wzięto pod uwagę 158 przedsiębiorstw (tabela 1), z czego z Polski pochodziło 33 podmioty (21\%), Czech - 58 (37\%), Słowacji - 32 (20\%) oraz Węgier - 35 (22\%).

Wśród badanej próby mikroprzedsiębiorstwa stanowiły 6,33\%, małe przedsiębiorstwa 39,24\%, zaś średnie przedsiębiorstwa stanowiły 54,43\% (tabela 2).

Tabela 2. Struktura wielkości analizowanych przedsiębiorstw

\begin{tabular}{|l|c|c|c|c|}
\hline \multicolumn{1}{|c|}{ Kraj } & Mikro & Małe & Średnie & RAZEM \\
\hline Polska & 4 & 13 & 16 & 33 \\
\hline Czechy & 2 & 21 & 35 & 58 \\
\hline Słowacja & 3 & 16 & 16 & 35 \\
\hline Węgry & 1 & 12 & 19 & 32 \\
\hline RAZEM & $10(6,33 \%)$ & $62(39,24 \%)$ & $86(54,43 \%)$ & $158(100 \%)$ \\
\hline
\end{tabular}

Źródło: opracowanie własne. 
Następnie w programie statystycznym Gretl 2018c utworzono model regresji liniowej, który uwzględnia dwie zmienne niezależne oraz jedną zmienną zależną.

$$
\text { export }=\beta_{0}+\beta_{1} \cdot \text { age }+\beta_{2} \cdot \text { fcapital }+\varepsilon
$$

Za zmienną zależną przyjęto intensywność eksportu mierzoną udziałem sprzedaży zagranicznej w sprzedaży ogółem, z kolei za zmienne niezależne przyjęto wiek startupu w momencie pierwszej internacjonalizacji oraz udział kapitału zagranicznego w strukturze właścicielskiej startupu.

Wychodząc od zdefiniowanej próby badawczej, w pracy testowane będą następujące hipotezy:

H1: Wiek startupu międzynarodowego wpływa istotnie na intensywności jego eksportu i jest z nim umiarkowanie (negatywnie) skorelowany.

H2: Udział kapitału zagranicznego w strukturze właścicielskiej startupu jest pozytywnie skorelowany z wiekiem startupu międzynarodowego.

H3: Udział kapitału zagranicznego w strukturze właścicielskiej startupu wpływa istotnie na intensywność jego eksportu i jest z nim pozytywnie skorelowany.

\section{WYNIKI BADAŃ I DYSKUSJA NAUKOWA}

Za pośrednictwem programu do analizy statystycznej Gretl (wersja 2018c) skonstruowano model regresji liniowej, gdzie zmienną zależną była intensywność eksportu (mierzona udziałem sprzedaży zagranicznej w całkowitych obrotach przedsiębiorstwa), z kolei zmiennymi niezależnymi były szybkość internacjonalizacji (mierzona wiekiem startupu w momencie pierwszej internacjonalizacji) oraz udział kapitału zagranicznego w strukturze właścicielskiej startupu.

W tabeli 3 zaprezentowano wyniki analizy korelacji pomiędzy zmiennymi wykorzystanymi w modelu. Na jej podstawie można stwierdzić, że intensywność eksportu jest negatywnie skorelowana z szybkością internacjonalizacji ( $r=-0,384, p<0,01)$. W kontekście istnienia zależności pomiędzy intensywnością eksportu i udziałem kapitału zagranicznego w strukturze właścicielskiej startupu sytuacja przedstawia się inaczej, tj. oba wskaźniki są pozytywnie ze sobą skorelowane $(r=0,195, p<0,01)$. Pomiędzy zmiennymi nie istnieje wysoka korelacja (tj. $r>0,7)$ dzięki czemu możemy je włączyć do oszacowanego modelu regresji.

Tabela 3. Macierz korelacji pomiędzy zmiennymi

\begin{tabular}{|l|c|c|c|}
\hline \multicolumn{1}{|c|}{ Zmienna } & EXPORT & AGE & FCAPITAL \\
\hline EXPORT & 1.000 & - & - \\
\hline AGE & $-0,384^{* * *}$ & 1.000 & - \\
\hline FCAPITAL & $0,195^{* * *}$ & $-0,100$ & 1,000 \\
\hline
\end{tabular}

Uwagi: $* * * p<0,01$.

Źródło: obliczenia własne w programie Gretl (2018c).

Współczynnik współliniowości (VIF - Variance Inflation Factor) dla zmiennych niezależnych w obu wypadkach wynosi 1.01 (zob. tabela 4), co oznacza, że pomiędzy nimi nie istnieje zjawisko kolinearności. Warto w tym miejscu wspomnieć, że wartości VIF większe 
od 5 (1/VIF < 0.2) mogą wskazywać na problem współliniowości - tzw. rozdęcia wariancji (Hair, 2006; Hair, Risher, Sarstedt \& Ringle, 2019).

W następnym kroku oszacowano parametry modelu regresji liniowej, której współczynniki zostały zaprezentowane w tabeli 4 . W celu uniknięcia zjawiska heteroskedastyczności w badaniu uwzględniano odporne błędy standardowe dla poszczególnych zmiennych objaśniających.

Tabela 4. Oszacowane parametry modelu regresji liniowej

\begin{tabular}{|l|c|c|c|c|}
\hline \multicolumn{1}{|c|}{ Zmienna } & Współczynnik & odp. bł. stan. & t & VIF \\
\hline AGE & $-0,074^{* * *}$ & 0,014 & $-5,227$ & 1,010 \\
\hline FCAPITAL & $0,112^{* *}$ & 0,047 & 2,401 & 1,010 \\
\hline Wyraz wolny & $0,693^{* * *}$ & 0,027 & 25,47 & \\
\hline \multicolumn{5}{|c|}{158} \\
\hline Liczba obs. & \multicolumn{4}{|c|}{$0,19,409^{* * *}$} \\
\hline F (3,154) & \multicolumn{4}{|c|}{0,162} \\
\hline R2 & \multicolumn{4}{|c|}{} \\
\hline Skor. R2 & \multicolumn{4}{|c|}{} \\
\hline
\end{tabular}

Uwagi: * $p<0.1, * * p<0.05, * * * p<0.01$.

Źródło: obliczenia własne w programie Gretl (2018c).

Tabela 4 pokazuje, że wartość skorygowanego współczynnika determinacji (R2) wynosi 0,162 . Oznacza to, że nieco ponad 16 procent całkowitej zmienności intensywności eksportu zostało wyjaśnione w modelu przez szybkość internacjonalizacji oraz udział kapitału zagranicznego w strukturze właścicielskiej startupu.

Na podstawie oszacowanych parametrów regresji liniowej (tabela 4) można stwierdzić, że wiek startupu międzynarodowego w momencie pierwszej internacjonalizacji wpływa istotnie na na intensywność jego eksportu $(p<0.01)$ oraz jest $z$ nią negatywnie powiązany. Wśród startupów, te które później realizują sprzedaż zagraniczną występuje niższa intensywność eksportu $(p<0.01)$, co zdaje się potwierdzać pierwszą hipotezę. Wyniki te są zbieżne z badaniami innych naukowców (Autio i in., 2000; Ciszewska-Mlinarič, 2018; Filatotchev, Stephan \& Jindra, 2008; Zhou, 2007). Para badaczy Fernández i Nieto (2006) wysunęła podobne wnioski co w niniejszym badaniu. Skonstruowany przez nich model ekonometryczny potwierdził ich przypuszczenia odnośnie do tego, że decyzja o wejściu na rynki zagraniczne jest pozytywnie powiązana m.in. z wiekiem przedsiębiorstwa oraz obecnością kapitału zagranicznego w strukturze właścicielskiej przedsiębiorstwa.

Udział kapitału zagranicznego w strukturze właścicielskiej startupu międzynarodowego również odgrywa istotną rolę strategiczną w wyjaśnianiu intensywności eksportu tych przedsięwzięć. Wzrost udziału kapitału zagranicznego o 1 pkt. procentowy skutkuje wzrostem intensywności eksportu o 0,112 pkt procentowego $(p<0.05)$. Wyniki są zbieżne z badaniami przeprowadzonymi przez innych badaczy (Abdel-Malek, 1974; Armario i in., 2008; Filatotchev i in., 2008; Peng, 2004; Sun \& Hong, 2011; Wąsowska, 2017). Warto w tym miejscu przytoczyć również wyniki badań Filatotchev i in. (2008), którzy to dowiedli, że równie istotnym aspektem wyjaśniającym intensywność eksportu w przedsiębiorstwach z kapitałem zagranicznym jest to, że inwestorzy zagraniczni bardzo często sprawują pieczę nad kluczowymi funkcjami zarządczymi w tych przedsiębiorstwach. 


\section{PODSUMOWANIE}

Przeprowadzone badania potwierdzają dwie spośród trzech postawionych hipotez (zob. tabela 5). Pierwsza hipoteza odnosząca się do tego, że wiek startupu międzynarodowego wpływa istotnie na intensywność jego eksportu została zweryfikowana za pośrednictwem regresji liniowej. Dodatkowo analiza korelacji wykazała istnienie ujemnej relacji między szybkością internacjonalizacji a intensywnością eksportu startupu międzynarodowego $(p<0,01)$.

Druga hipoteza dotyczyła istnienia dodatniej korelacji pomiędzy udziałem kapitału zagranicznego w strukturze właścicielskiej startupu międzynarodowego a szybkością jego internacjonalizacji. Hipoteza została odrzucona, gdyż zauważona relacja miała kierunek ujemny $(r=-0,10)$ i była nieistotna statystycznie, stąd rekomendacją jest dalsze wyjaśnienie tej kwestii w kolejnych badaniach.

Trzecia hipoteza potwierdziła przypuszczenia, że kapitał zagraniczny w startupie międzynarodowym wpływa istotnie na intensywność jego eksportu $(p<0.05)$, oraz obie zmienne są ze sobą dodatnio skorelowane $(p<0.01)$.

Tabela 5. Weryfikacja hipotez badawczych

\begin{tabular}{|l|c|c|}
\hline \multicolumn{1}{|c|}{ Hipotezy badawcze } & Weryfikacja & Metoda weryfikacji \\
\hline $\begin{array}{l}\text { H1: Wiek startupu międzynarodowego wpływa istotnie na } \\
\text { intensywność jego eksportu i jest z nim umiarkowanie (ne- } \\
\text { gatywnie) skorelowany. }\end{array}$ & potwierdzona & $\begin{array}{c}\text { Analiza korelacji } \\
\text { Analiza regresji }\end{array}$ \\
\hline $\begin{array}{l}\text { H2: Udział kapitału zagranicznego w strukturze właściciel- } \\
\text { skiej startupu jest pozytywnie skorelowany z wiekiem star- } \\
\text { tupu międzynarodowego. }\end{array}$ & niepotwierdzona & Analiza korelacji \\
\hline $\begin{array}{l}\text { H3: Udział kapitału zagranicznego w strukturze właściciel- } \\
\text { skiej startupu wpływa istotnie na intensywność eksportu i } \\
\text { jest z nim pozytywnie skorelowany. }\end{array}$ & potwierdzona & $\begin{array}{c}\text { Analiza korelacji } \\
\text { Analiza regresji }\end{array}$ \\
\hline
\end{tabular}

Źródło: opracowanie własne

Jak każde badanie empiryczne, również i to nie jest wolne od swoich ograniczeń. Po pierwsze zostało ono oparte na bazie danych BEEPS, w której znalazły się tylko wybrane przedsiębiorstwa. Po drugie, część rekordów odnoszących się do pytań skierowanych do przedsiębiorstw zostały usunięte z powodu braku odpowiedzi (zabieg ten miał na celu wybranie tylko tych przedsiębiorstw, które posiadały kompletne dane). Po trzecie, w modelu uwzględniono tylko i wyłącznie dwie zmienne niezależne, stąd warto by było w kolejnych badaniach rozszerzyć model o kolejne zmienne.

Obecnie brak jest odpowiedniej liczby badań dotyczących intensywności eksportu startupów międzynarodowych. Kolejne badania powinny uwzględniać znaczenie kapitału zagranicznego w kształtowaniu polityki eksportowej tych przedsięwzięć. Część badaczy twierdzi, że startupy (międzynarodowe) są również finansowane za pośrednictwem kapitału podwyższonego ryzyka (venture capital), dlatego też ciekawym zagadnieniem mogłoby się wydawać przeanalizowanie zależności pomiędzy obecnością zagranicznych funduszy podwyższonego ryzyka (venture capital) w startupach międzynarodowych a intensywnością ich eksportu. Zaleca się jednak, aby w dalszym modelowaniu wykorzystywać więcej zmiennych. 


\section{LITERATURA}

Abdel-Malek, T. (1974). Foreign Ownership and Export Performance. Journal of International Business Studies, 5(2), 1-14.

Armario, J.M., Ruiz, D.M. \& Armario, E.M. (2008). Market Orientation and Internationalization in Small and Medium-Sized Enterprises. Journal of Small Business Management, 46(4), 485-511. https://doi.org/10.1111/j.1540-627X.2008.00253.x

Autio, E., Sapienza, H.J. \& Almeida, J.G. (2000). Effects of Age at Entry, Knowledge Intensity, and Imitability on International Growth. Academy of Management Journal, 43(5), 909-924. https://doi.org/10.5465/1556419

Bell, J., Crick, D. \& Young, S. (2004). Small Firm Internationalization and Business Strategy: An Exploratory Study of 'Knowledge-Intensive' and 'Traditional' Manufacturing Firms in the UK. International small business journal, 22(1), 23-56.

Blesa, A., Ripolles, M. \& Monferrer, D. (2010). Marketing capabilities: do they matter in INVs? World Review of Entrepreneurship, Management and Sustainable Development, 6(1/2), 71. https://doi.org/10.1504/WREMSD.2010.031639

Chetty, S., Johanson, M. \& Martín Martín, O. (2014). Speed of internationalization: Conceptualization, measurement and validation. Journal of World Business, 49(4), 633-650. https://doi.org/10.1016/j.jwb.2013.12.014

Ciszewska-Mlinarič, M. (2018). Export Intensity, Geographic Diversification and the Role of Public Support: The Evidence from Old and New Europe SMEs. Entrepreneurial Business and Economics Review, 6(2), 45-69. https://doi.org/10.15678/EBER.2018.060203

Davila, A., Foster, G. \& Gupta, M. (2003). Venture capital financing and the growth of startup firms. Journal of Business Venturing, 18(6), 689-708. https://doi.org/10.1016/S0883-9026(02)00127-1

Duliniec, E. (2011). Early Internationalizing Firms: Discussion of Terminology. Gospodarka Narodowa, 245(1-2), 63-80. https://doi.org/10.33119/GN/101089

Ellis, P. (2000). Social Ties and Foreign Market Entry. Journal of International Business Studies, 31(3), 443-469. https://doi.org/10.1057/palgrave.jibs.8490916

Ellis, P. \& Pecotich, A. (2001). Social Factors Influencing Export Initiation in Small and Medium-Sized

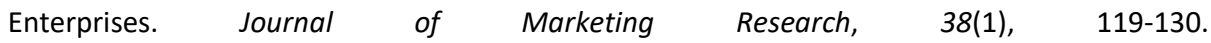
https://doi.org/10.1509/jmkr.38.1.119.18825

Etemad, H. (2004). International Entrepreneurship as a Dynamic Adaptive System: Towards a Grounded Theory. Journal of International Entrepreneurship, 2(1-2), 5-59.

Fernández, Z. \& Nieto, M.J. (2006). Impact of ownership on the international involvement of SMEs. Journal of International Business Studies, 37(3), 340-351. https://doi.org/10.1057/palgrave.jibs. 8400196

Filatotchev, I., Hoskisson, R.E., Buck, T. \& Wright, M. (1996). Corporate Restructuring in Russian Privatizations: Implications for U.S. Investors. California Management Review, 38(2), 87-105. https://doi.org/10.2307/41165834

Filatotchev, I., Stephan, J. \& Jindra, B. (2008). Ownership structure, strategic controls and export intensity of foreign-invested firms in transition economies. Journal of International Business Studies, 39(7), 1133-1148. https://doi.org/10.1057/palgrave.jibs.8400404

Hagen, B., Zucchella, A., Cerchiello, P. \& de Giovanni, N. (2012). International strategy and performance-Clustering strategic types of SMEs. International Business Review, 21(3), 369-382.

Hair, J. F. (2006). Multivariate data analysis (6th ed.). Upper Saddle River, N.J.: Pearson Prentice Hall. 
Hair, J.F., Risher, J.J., Sarstedt, M. \& Ringle, C.M. (2019). When to use and how to report the results of PLS-SEM. European Business Review, 31(1), 2-24. DOI: https://doi.org/10.1108/EBR-11-2018-0203.

Hashai, N. \& Almor, T. (2004). Gradually Internationalizing 'Born Global' Firms: An Oxymoron? International Business Review, 13(4), 465-483.

He, X. \& Wei, Y. (2011). Linking market orientation to international market selection and international performance. International Business Review, 20(5), 535-546. https://doi.org/10.1016/j.ibusrev.2010.10.003

Hellmann, T.F. \& Puri, M. (2002). Venture Capital and the Professionalization of Start-Up Firms: Empirical Evidence. Journal of Finance, 57, 169-197.

Invest Europe. (2017). Central and Eastern Europe. Private Equity Statistics. Pobrane z: https://www.investeurope.eu/media/727455/Invest-Europe-CEE-Activity-Report-201705072018.pdf

Jantunen, A., Nummela, N., Puumalainen, K. \& Saarenketo, S. (2008). Strategic orientations of born globals-Do they really matter? Journal of World Business, 43(2), 158-170.

Johanson, J. \& Vahlne, J.-E. (1974). The internationalization Process of the Firm. Mimeographed Working Paper, Uppsala: Department of Business Administration.

Johanson, J. \& VahIne, J.-E. (1977). The Internationalization Process of the Firm - A Model of Knowledge Development and Increasing Foreign Market Commitments. Journal of International Business Studies, 8(1), 23-32. https://doi.org/10.1057/palgrave.jibs.8490676

Johanson, J. \& Wiedersheim-Paul, F. (1975). The Internationalization of the Firm - Four Swedish Cases. Journal of Management Studies, 12(3), 305-323. https://doi.org/10.1111/j.14676486.1975.tb00514.x

Kalinic, I. \& Forza, C. (2012). Rapid internationalization of traditional SMEs: Between gradualist models and born globals. International Business Review, 21(4), 694-707. https://doi.org/10.1016/j.ibusrev.2011.08.002

Knight, G. A. \& Cavusgil, S.T. (2004). Erratum: Innovation, organizational capabilities, and the bornglobal firm. Journal of International Business Studies, 35(4), 334. https://doi.org/10.1057/palgrave.jibs.8400096

Knight, G.A. \& Cavusgil, S.T. (2005). A Taxonomy of Born-global Firms. Management International Review, 45(3), 15-35.

Knight, G., Madsen, T.K. \& Servais, P. (2004). An inquiry into born-global firms in Europe and the USA. International Marketing Review, 21(6), 645-665. https://doi.org/10.1108/02651330410568060

Kumar, V., Stam, A. \& Joachimsthaler, E.A. (1994). An Interactive Multicriteria Approach to Identifying Potential Foreign Markets. Journal of International Marketing, 2(1), 29-52.

Maciejewski, M. (2018). International startups as the essence of international entrepreneurship. In: K. Wach (Ed.), Intenationalisation of Firms in the perspective of international entrepreneurship (pp. 97-118). Warsaw: PWN.

Madsen, T.K., Rasmussen, E. \& Servais, P. (2000). Differences and similarities between born globals and other types of exporters. In: A. Yaprak \& H. Tutek (Eds.), Globalization, the Multinational Firm, and Emerging Economies (pp. 247-265). Emerald Group Publishing Limited.

McDougall, P.P. (1989). International versus domestic entrepreneurship: New venture strategic behavior and industry structure. Journal of Business Venturing, 4(6), 387-400. https://doi.org/10.1016/0883-9026(89)90009-8

McNaughton, R.B. \& Bell, J. (2004). Capital Structure and the Pace of SME Internationalization. In: H. Etemad (Ed.), International entrepreneurship in small and medium size enterprises. Orientation, environment and strategy (pp. 57-71). Cheltenham, Northampton: Edward Elgar. 
Mejri, K. \& Umemoto, K. (2010). Small- and medium-sized enterprise internationalization: Towards the knowledge-based model. Journal of International Entrepreneurship, 8(2), 156-167.

Monferrer, D., Blesa, A. \& Ripollés, M. (2012). International Market Orientation and Management Capabilities as Determinants of the New Ventures' International Behaviour. Economics Research International, 2012(4), 1-14. https://doi.org/10.1155/2012/623685

OECD. (2017). Venture Capital Investments: Entrepreneurship at Glance 2017. Paris: OECD Publishing.

Oviatt, B.M. \& McDougall, P.P. (1994). Toward a Theory of International New ventures. Journal of International Business Studies, 25(1), 45-64. https://doi.org/10.1057/palgrave.jibs.8490193

Oviatt, B.M. \& McDougall, P.P. (2005). Toward a theory of international new ventures. Journal of International Business Studies, 36(1), 29-41. https://doi.org/10.1057/palgrave.jibs.8400128

Papadopoulos, N., Chen, H. \& Thomas, D.R. (2002). Toward a tradeoff model for international market selection. International Business Review, 11(2), 165-192. https://doi.org/10.1016/S09695931(01)00054-3

Peng, M.W. (2004). Outside directors and firm performance during institutional transitions. Strategic Management Journal, 25(5), 453-471. https://doi.org/10.1002/smj.390

Pohl, G., Anderson, R.E., Claesson, S. \& Dejankov, S. (1997). Privatization and Restructuring in Central and Eastern Europe. Washington DC.: World Bank.

Ruzzier, M., Hisrich, R.D. \& Antoncic, B. (2006). SME internationalization research: past, present, and future. Journal of Small Business and Enterprise Development, 13(4), 476-497. https://doi.org/10.1108/14626000610705705

Schweizer, R., Vahlne, J.-E. \& Johanson, J. (2010). Internationalization as an entrepreneurial process. Journal of International Entrepreneurship, 8(4), 343-370. https://doi.org/10.1007/s10843-010-0064-8

Schwens, C., Steinmetz, H. \& Kabst, R. (2010). Growth and Internationalization: Renewable Energy and New Technology-Based Firms. In: A. Gerybadze, U. Hommel, H. W. Reiners, D. Thomaschewski (Eds.), Innovation and International Corporate Growth (pp. 113-123). Berlin, Heidelberg: Springer Berlin Heidelberg.

Sun, X. \& Hong, J. (2011). Exports, Ownership and Firm Productivity: Evidence from China. The World Economy, 34(7), 1199-1215. https://doi.org/10.1111/j.1467-9701.2011.01373.x

Turcan, R. (2013). International New Venture Legitimation: An Exploratory Study. Administrative Sciences, 3(4), 237-265. https://doi.org/10.3390/admsci3040237

Wach, K. (2012). Europeizacja małych i średnich przedsiębiorstw: Rozwój przez umiędzynarodowienie. Warszawa: Wydawnictwo Naukowe PWN.

Wach, K. (2015). Entrepreneurial Orientation and Business Internationalisation Process: The Theoretical Foundations of International Entrepreneurship. Entrepreneurial Business and Economics Review, 3(2), 9-24. https://doi.org/10.15678/EBER.2015.030202

Wach, K. (2018). Theoretical foundations for international entrepreneurship. In: K. Wach (Ed..), Intenationalisation of Firms in the perspective of international entrepreneurship (pp. 63-95). Warsaw: PWN.

Wąsowska, A. (2017). The Internationalisation of Family Firms: the Role of the Ownership Structure and the Composition of Top Management Team. Entrepreneurial Business and Economics Review, 5(1), 169-185. https://doi.org/10.15678/EBER.2017.050110

Zahra, S.A. (1993). A Conceptual Model of Entrepreneurship as Firm Behavior: A Critique and Extension. Entrepreneurship Theory and Practice, 17(4), 5-21. https://doi.org/10.1177/104225879301700401

Zahra, S.A. (2005). A theory of international new ventures: a decade of research. Journal of International Business Studies, 36(1), 20-28. https://doi.org/10.1057/palgrave.jibs.8400118 
Zahra, S.A., Zheng, C. \& Yu, J. (2018). Learning advantages of newness: A reconceptualization and contingent framework. Journal of International Entrepreneurship, 23(5), 567. https://doi.org/10.1007/s10843-017-0202-7

Zhou, L. (2007). The effects of entrepreneurial proclivity and foreign market knowledge on early internationalization. Journal of World Business, 42(3), 281-293. https://doi.org/10.1016/j.jwb.2007.04.009

The journal is co-financed in the years 2019-2020 by the Ministry of Science terial programme "Support for Scientific Journals" (WCN) on the basis of contract no. 238/WCN/2019/1 concluded on 15 August 2019. 


\section{Tytuł i abstrakt w języku angielskim}

\section{The Influence of the Speed of Internationalisation and Foreign Capital on the Export Intensity: The Case of International Startups}

The main aim of the article is to present the results of research on international startups, taking into account the importance of the speed of internationalisation and foreign capital in explaining their export intensity based on the results from the Visegrad countries. The article, apart from the literature review and its criticism, is based on data collected within the framework of the BEEPS survey, which was conducted mainly among enterprises located in post-communist countries in Europe and Central Asia. After appropriate selection, 158 international startups from Poland, the Czech Republic, Slovakia or Hungary were finally selected. The study examined the relationship between the export intensity of the international startup and the speed of its internationalisation. Moreover, the influence of foreign capital on the export intensity of international startup was also examined. The internationalisation of startups is very rapid. Moreover, the results of the study show that the share of foreign capital in the ownership structure of the startup is very important, as it contributes to increasing its export intensity. The article enriches the ongoing scientific discourse on the role of foreign capital and the speed of internationalisation in international startups.
Keywords: international startups; international new ventures; foreign capital; speed of in- JEL codes: $\quad$ F23, L26, M13

\section{Autor}

\section{Krystian Bigos}

Asystent w Katedrze Handlu Zagranicznego Uniwersytetu Ekonomicznego w Krakowie. Jego zainteresowania koncentrują się wokół przedsiębiorczości międzynarodowej.

Adres do korespondencji: mgr Krystian Bigos, Uniwersytet Ekonomiczny w Krakowie, Katedra Handlu Zagranicznego, ul. Rakowicka 27, 31-510 Kraków, e-mail: bigosk@uek.krakow.pl ORCID (1) http://orcid.org/0000-0001-6030-4119

\section{Podziękowania i finansowanie}

Publikacja została sfinansowana/dofinansowana ze środków MNiSW przyznanych Wydziałowi Ekonomii i Stosunków Międzynarodowych Uniwersytetu Ekonomicznego w Krakowie na badania dla młodych naukowców oraz uczestników studiów doktoranckich (nr 165/WE-KHZ/02/2018/M/8165).

\section{Prawa autorskie}

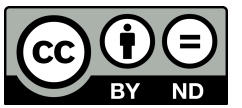

Ten artykuł został opublikowany na warunkach Creative Commons Uznanie autorstwa - Bez utworów zależnych (CC BY-ND 4.0 License) http://creativecommons.org/licenses/by-nd/4.0/ 
